\title{
Diversifikasi Usaha Kelompok Penjual Jamu Gendong Melalui Pembuatan TOGA Instan dan Sirup TOGA
}

\author{
Sukarjati $^{1 *}$, Diah Karunia Binawati ${ }^{1}$, Vivin Andriani ${ }^{1}$ \\ ${ }^{1}$ Program Studi Biologi, Universitas PGRI Adi Buana, Surabaya, Indonesia \\ *Email: sukarjati@unipasby.ac.id
}

\begin{abstract}
Informasi Artikel Abstrak
Kata kunci:

Kelompok Penjual Jamu gendong, Toga instan, Sirup Toga, Pendapatan

Diterima: 01-09-2021

Disetujui: 10-01-2022

Dipubikasikan: 28-012022

Jamu gendong dibuat dari bahan tanaman obat keluarga (TOGA). Penjual jamu gendong belum memanfaatkan dan belum mengelola potensi tanaman obat secara optimal. Berjualan jamu dengan digendong atau bersepeda menyebabkan area penjualan terbatas dan bila hujan tidak berjualan menyebabkan penghasilannya tidak ajeg. Jamu gendong yang dijual tidak hygienis karena menggunakan botol plastik bekas yang tidak diganti bila tidak rusak. Pembuatan TOGA instan dan Sirup Toga merupakan solusi untuk mengatasi masalah tersebut. Metode pelaksanaan yang dilakukan dengan memberikan penyuluhan tentang pemilihan bahan yang berkualitas, pelatihan cara mengolah bahan jamu gendong yang hygienis, pelatihan dan pendampingan dalam pembuatan TOGA instan dan Sirup TOGA serta dilakukan pendampingan dan pelatihan tentang stategi pemasaran dan manajemen produksi. Hasil pelaksanaan kegiatan ini adalah kelompok penjual jamu gendong telah berhasil membuat dan memasarkan produk TOGA instan dan sirup TOGA dan Jamu gendong yang dijual menggunakan botol kaca dan hygienis. Dengan demikian pendapatan penjual jamu gendong meningkat dan ajeg.
\end{abstract}

\section{Keywords :}

Carrying Herb Seller Group, Instant Toga, Toga Syrup, Income

\section{Abstract}

Jamu Gendong made of medicinal plant materials. The sellers of jamu gendong not utilize and manage the potential of medicinal plants has not been optimally. Selling jamu gendong or cycling causes the sales area is limited and when the rain does not sell cause no steady income. Jamu gendong sold not hygienic because it uses plastic bottles are not replaced when it is not broken. Making an instant and Toga Syrup is a solution to overcome the problem. The method implementation is done by providing information about the selection of quality materials, training in how to process jamu gendong hygienic, training and mentoring in the manufacture of instant and syrup Toga and do mentoring and training in marketing strategy and production management. The results of this activity is the sellers of jamu gendong has successfully made and market the products that is instant and syrup toga and jamu gendong are sold using glass bottles and hygienic. Thus carrying herbalist revenue increased and steady. 


\section{PENDAHULUAN}

Jamu gendong merupakan campuran atau ramuan bermacam-macam simplisia dari tanaman berkhasiat obat dan tersedia dalam bentuk cairan yang bisa langsung dikonsumsi oleh masyarakat. Jamu gendong pada umumnya dikonsumsi oleh masyarakat sebagai minuman kesehatan sehari-hari dan minuman pelepas dahaga. Jamu beras kencur, kunir asam, dan cabe puyang merupakan jamu gendong yang sering dikonsumsi masyarakat setiap harinya. Jamu gendong merupakan obat tradisional yang telah dikenal masyarakat Indonesia sejak berabad-abad yang lalu. Obat tradisional ini merupakan warisan leluhur bangsa Indonesia dan banyak digunakan untuk memenuhi kebutuhan kesehatan. Pembuatan jamu gendong sebagai obat tradisional didasarkan pada pengalaman secara turun termurun berdasarkan pengetahuan dan ketrampilan yang diwariskan nenek moyang. Keaslian racikan turun temurun obat tradisional jamu gendong ini masih tetap lestari sampai sekarang. Sebagai salah satu kekayaan budaya asli Indonesia, jamu gendong patut dilestarikan (Hersoelistyorini et al., 2016) Hasil penelitian yang dilakukan oleh (Wulandari \& Azrianingsih, 2014) didapatkan hasil bahwa Masyarakat tetap gemar mengonsumsi jamu gendong, baik dari anak-anak sampai orang tua, karena jamu gendong masih dipercaya khasiatnya dan aman dikonsumsi. Oleh sebab itu, kebudayaan minum jamu tetap dilestarikan dalam rangka untuk melestarikan warisan budaya dan keragaman hayati lokal. Ciri khas dari penjual jamu gendong adalah perempuan membawa bakul yang di dalamnya berisi botol jamu dengan cara digendong, sementara tangan kiri memegang ember untuk mencuci gelas setelah dipakai untuk minum jamu (Suci Asriani et al., 2015). Sistem Medis modern mencoba menyatukan penggunaan tanaman obat dan Pengobatan modern pada dekade terakhir ini. Alasannya antara lain adalah (1) Murah, (2) Tanaman obat mampu mencegah resistensi patogen, (3) Banyak penyakit yang belum dapat disembuhkan secara efektif oleh pengobatan modern). Hasil penelitian di laboratorium semakin menguatkan keamanan dan kemanjuran tanaman obat secara klinis. Jamu gendong di buat dari bahan tanaman obat (TOGA/Tanaman Obat Keluarga), dimana TOGA dahulu dikenal dengan sebutan Apotek Hidup. Namun dalam proses pembuatan jamu gendong dari hasil beberapa penelitian kurang memenuhi standar yang ditetapkan Pemerintah. Pemerintah perlu mengadakan penyuluhan kepada penjual jamu gendong mengenai sanitasi dan higiene dalam proses peracikan jamu gendong di kota Malang; Sedangkan menurut (Nurrahman, Mifbakhuddin, 2010), jamu gendong yang diproduksi di Kedung Mundu Tembalang Semarang, tidak memenuhi persyaratan Total Koliform. Hal yang sama juga didapatkan 
pada penelitian (Tivani, 2018) yang menyatakan bahwa jamu kunyit asam yang di jajakan di Kecamatan talang kabupaten tegal belum memenuhi syarat mutu dilihat dari ALT (Angka Lempeng Total). Dengan demikian diperlukan pelatihan dan pendampingan pembuatan jamu gendong yang aman dan hygienis pada pembuat jamu gendong.

Desa Bohar terletak di kecamatan Taman kota Sidoarjo terdapat kelompok penjual jamu gendong. Berikut adalah kondisi 2 ibu penjual jamu gendong sebagai Mitra. Ibu Yanti berasal dari kota Solo desa Sukoharjo. Sejak tahun 1993 merantau ke Sidoarjo dan menetap di desa Bohar hingga sekarang. Ibu Yanti berjualan jamu gendong di Desa Bohar sudah 14 tahun. Jamu yang dijual adalah suruh kunci, beras kencur, kunyit asem, sinom, kunyit putih, temulawak, luntas, dan pahitan. Bahan jamu gendong mudah diperoleh di pasar. Ibu yanti menjajakan jamu gendong disekitar desa Bohar mulai pukul 07.00 hingga 11.00. Jamu yang sering tersisa adalah pahitan. Proses pembuatan jamu gendong ini masih tradisional karena bahan jamu ditumbuk menggunakan lumpang batu. Maksimum perhari bisa membuat 15 botol. Jamu gendong ini dibuat mulai jam 03.00 pagi. Keluhan utama yang dialami Ibu Yanti adalah, peralatan penumbuk jamu yang hanya menggunakan lumpang batu membuat ibu yanti hanya mampu memproduksi 15 botol per hari. Menjajakan jamu dengan berjalan kaki menyebabkan area penjualan hanya sekitar satu kilo. Disamping itu bila hari hujan ibu yanti tidak berjualan. Ibu Mursih juga berasal dari Solo. Berjualan jamu gendong yang dijajakan menggunakan sepeda. Ibu Mursih berjualan jamu gendong sudah 18 tahun. Sama halnya dengan ibu Yanti, Ibu mursih juga membuat jamu dengan di tumbuk menggunakan lumpang batu. Jenis jamu yang dijual ibu Mursih sama dengan ibu Yanti hanya saja ibu Mursih juga menjual jamu bubuk produksi kota Solo. Pengalaman ke dua ibu penjual jamu gendong ini yaitu ibu Yanti (berjualan jamu gendong selama 14 tahun) dan Ibu mursih (berjualan jamu gendong selama 18 tahun) merupakan wanita pekerja keras dan mempunyai minat yang tinggi untuk belajar serta sangat besar keingininannya untuk mengembangkan usaha.
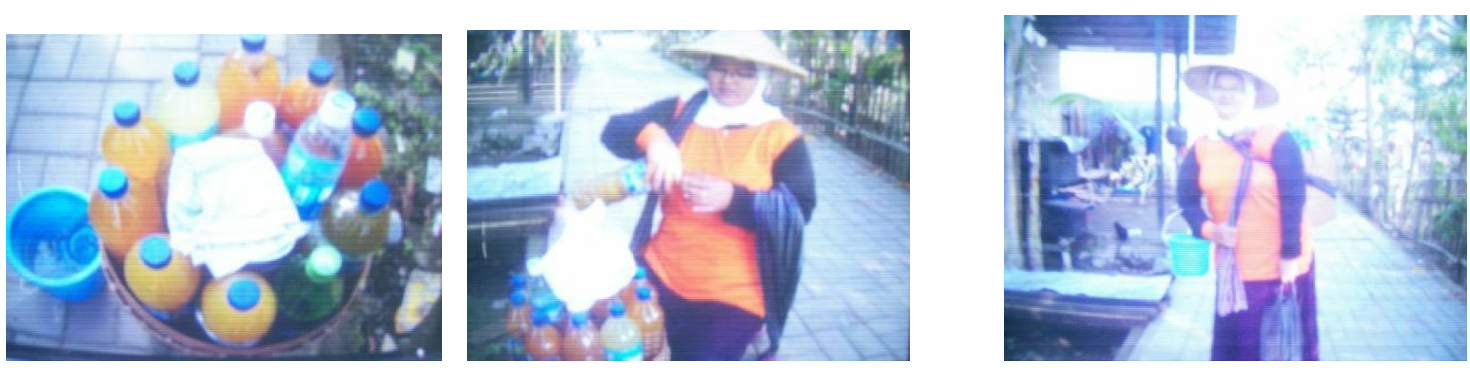

Gb 1: Bakul jamu gendong Gb.2: Ibu Yanti melayani pembeli Gb.3: Ibu Yanti menjajakan jamu 
Permasalahan mitra adalah keterbatasan kemampuan dan pengetahuan penjual jamu gendong terhadap pemanfaatan dan pengelolaan potensi tanaman obat. Tanaman obat hanya dimanfaatkan sebagai jamu gendong dan dalam penjualan yang terbatas baik lokasi maupun produksinya. Untuk itu dibutuhkan pembekalan pengetahuan berupa penyuluhan, pendampingan tentang diversifikasi pemanfaatan tanaman obat (toga instan dan sirup toga) dengan memberikan ketrampilan pembuatan toga instan dan sirup toga. Disamping itu keterbatasan produksi jamu gendong tersebut (hanya 15 botol per hari) dikarenakan keterbatasan alat dan cara pengolahan yang masih tradisional menggunakan lumpang batu sehingga memerlukan waktu yang lama. Penggunaan botol minuman berbahan plastik yang tidak diganti bila tidak rusak menjadi jamu yang di jual tidak hygenis. Menjual jamu dengan digendong dan bejalan kaki atau dengan bersepeda menyebabkan penjual jamu terbatas area penjualannya. Disamping itu bila hujan tidak bisa berjualan. Hal tersebut menyebabkan bila hujan tidak ada penghasilan. Untuk itu dengan memberikan ketrampilan membuat toga instan dan sirup toga merupakan solusi karena toga instan dan sirup toga dapat diproduksi dan dipasarkan tidak tergantung cuaca dan dapat meningkatkan dan ke ajeg an dalam memperoleh penghasilan.

\section{METODE PELAKSANAAN}

\section{Tahap Persiapan}

1. Melakukan koordinasi terkait kesediaan dilakukannya pendampingan pembuatan toga instan dan sirup toga pada kelompok pembuat jamu gendong di Desa Bohar

2. Melakukan ijin kepada Kepala Desa Bohar terkait dengan program tersebut.

3. Melakukan koordinasi dengan kelompok penjual jamu gendong terkait jadwal pelaksanaan pelatihan dan pendampingan.

4. Menyiapkan bahan dan alat. Adapun bahan tersebut meliputi Jahe, Temulawak, kunyit putih, Kunyit, Gula pasir, gula merah, asam jawa, garam dan air. Alatnya meliputi Parut, panci, wajan, pengaduk, plastic, sealer, botol

\section{Tahap Pelaksanaan:}

1. Dilakukan Kegiatan pelatihan dan pendampingan pembuatan toga instan

2. Dilakukan kegiatan pelatihan dan pendampingan pembuatan sirup toga

3. Dilakukan kegiatan pelatihan dan pendampingan pengemasan produk toga instan dan sirup toga

4. Dilakukan pemberian fasilitas dan dilakukan pendampingan cara mengoperasionalkan alat. 
Aktivitas kegiatan dilakukan pada rumah salah satu pembuat jamu gendong. Ada 4 Ibu pembuat jamu gendong. Masing masing ibu pembuat jamu gendong berlatih membuat satu jenis toga instan dan satu jenis sirup toga.

Adapun Prosedur pembuatan Toga instan tersebut sebagai berikut:

\section{Pembuatan Jahe Instan}

Satu Kg rimpang Jahe yang sehat dan tidak busuk, dipilih jahe yang tidak terlalu tua atau terlalu muda.Rimpang jahe dikupas kemudian dicuci. Jahe diparut dan ditambah air sedikit demi sedikit hingga volume air yang ditambahkan satu liter sehingga diperoleh air perasan jahe. Air perasan jahe di endapkan sekitar 3-4 jam. Bagian endapan dibuang dan diperoleh sari jahe. Sari jahe sebanyak satu liter dituang dalam wajan dan ditambah $1 \mathrm{Kg}$ gula selanjutnya dimasak hingga mengkristal. Kristal dihancurkan dan di lakukan pengayakan maka akan diperoleh jahe instan.

Pembuatan Kunyit putih instan dan temulawak instan sama dengan pembuatan jahe instan.

\section{Pembuatan Kunyit asam instan}

$1 \mathrm{Kg}$ kunyit yang segar dan tidak cacat dikupas dan di cuci bersih selanjutnya diparut dan diperas dengan menambahkankan sedikit demi sedikit hingga volume 1 liter. Air perasan didiamkan selama 3-4 jam. Selanjutnya endapan dibuang dan telah diperoleh sari kunyit. Larutan asam jawa dibuat dengan cara memasukkan $1 / 4 \mathrm{Kg}$ asam jawa pada500 $\mathrm{ml}$ air mendidih dan diamkan. Selanjutnya 1 liter sari kunyit ditambah air asam jawa $500 \mathrm{ml}$ ditambah gula 1,5 Kg dimasak sehingga didapatkan Kristal kunyit asam. Kristal kunyit asam di haluskan dan di ayak, maka kunyit asam instan siap dikemas.

Berikut adalah foto kegiatan saat pelaksanaan pendampingan pembuatan toga instan.

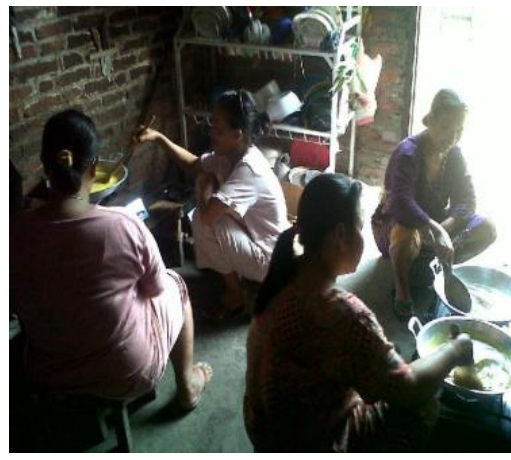

Gambar 4

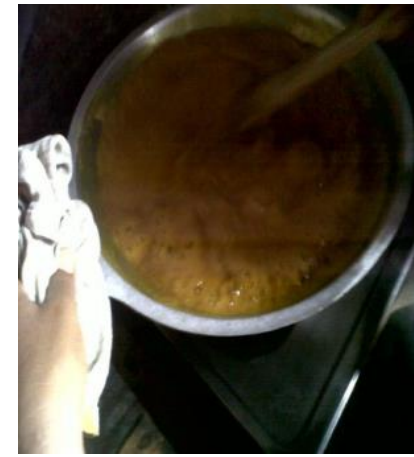

Gambar.5

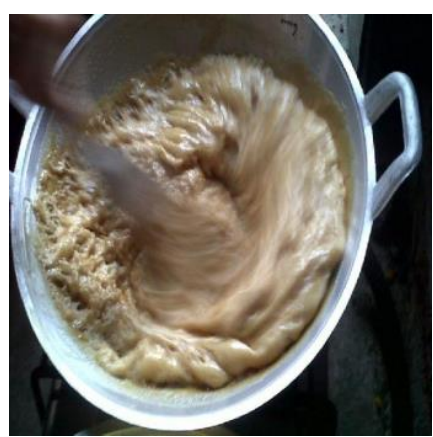

Gambar 6 


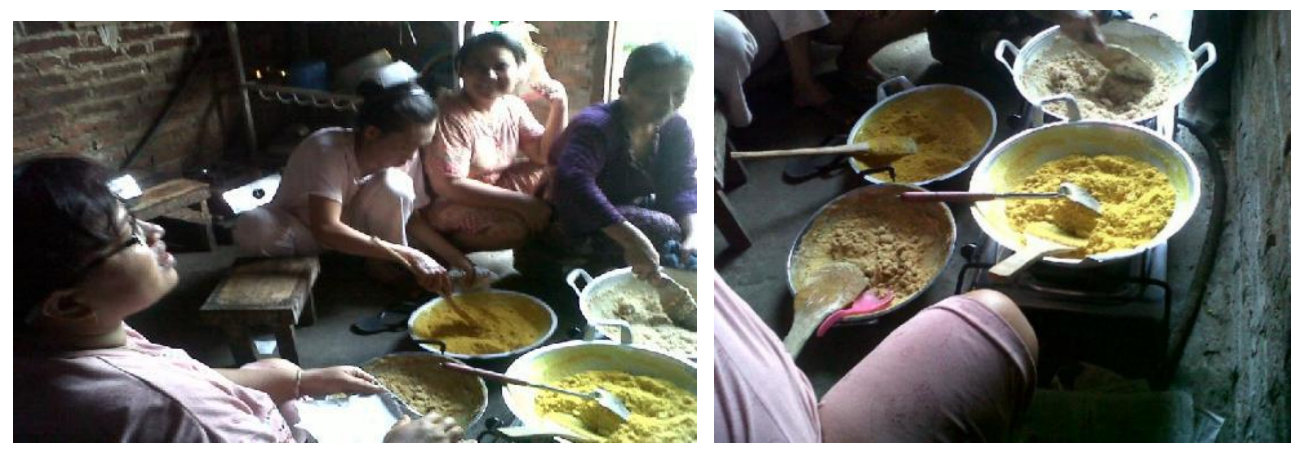

Gambar 7

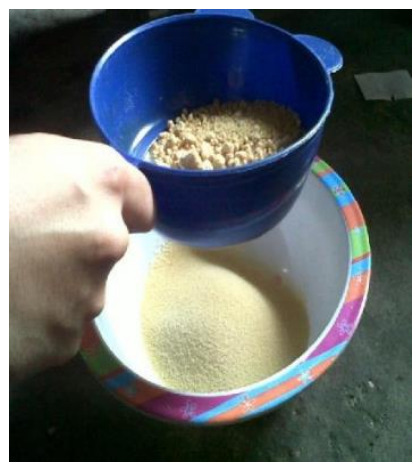

Gambar 9

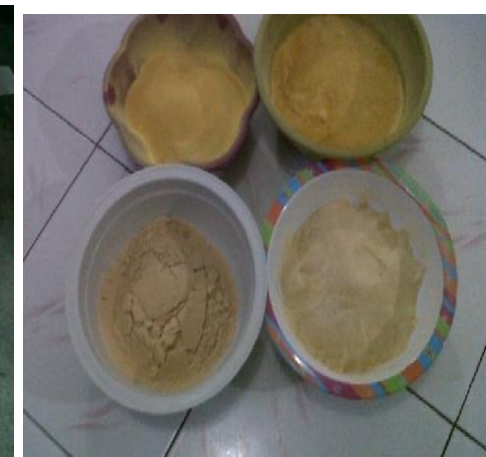

Gambar 10

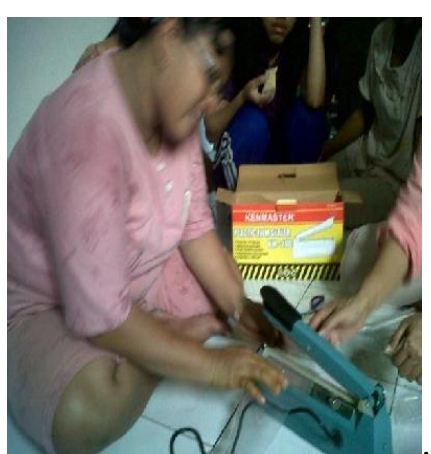

Gambar 11

Keterangan:

Gambar 4: Ibu ibu penjual jamu sedang memasak sari toga

Gambar 5: Sari Toga telah mendidih

Gambar 6: Sari toga membentuk busa pekat

Gambar 7: Sari Toga telah di angkat dari kompor dan mengkristal dan menjadi instan toga

Gambar 8: Toga instan didinginkan

Gambar 9 : Toga instan di ayak

Gambar 10: Toga instan yang telah halus

Gambat 11: Toga instan dikemas dalam platik dan di rekat dengan sealer

\section{Pembuatan Sirup Toga}

\section{Pembuatan Sirup Toga sebagai berikut}

\section{Pembuatan Sirup Jahe.}

1 liter Sari jahe (dibuat seperti membuat sari jahe pada pembuatan jahe instan) ditambah $2 \mathrm{Kg}$ gula pasir kemudian dimasak sampai mendidih dan agak mengental. Setelah dingin di masukkan botol dan diberi label.Pembuatan sirup temulawak dan sirup kunyit putih sama dengan pembuatan sirup jahe.

\section{Pembuatan sirup kunyit asam}

Pembuatan sari kunyit dan air asam jawa sama pada pembuatan kunyit asam instan. 1 liter sari kunyit dan $100 \mathrm{ml}$ air asam ditambah $1.5 \mathrm{Kg}$ Gula pasir dimasak hingga mendidih dan agak mengental.

Setelah dingin siap dikemas pada botol yang telah disterilisasi.

\section{Berikut adalah foto kegiatan pembuatan sirup Toga}



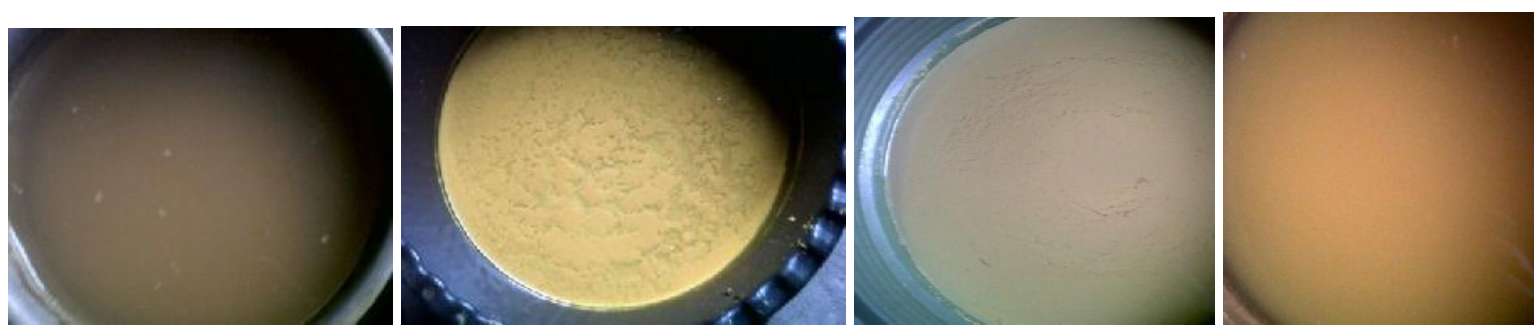

Gb.12; Sari jahe

Gb.13: Sari temulawak

Gb. 14:Kunyit Putih

Gb.15: Kunyit

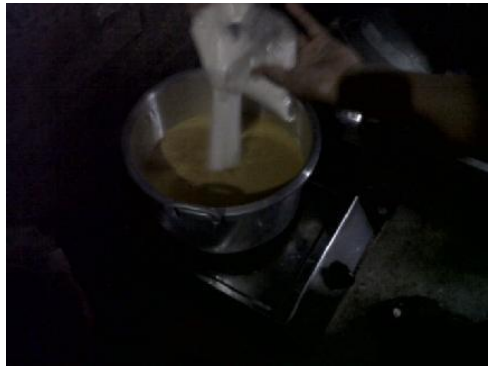

Gb.16: Penambahan gula pasir

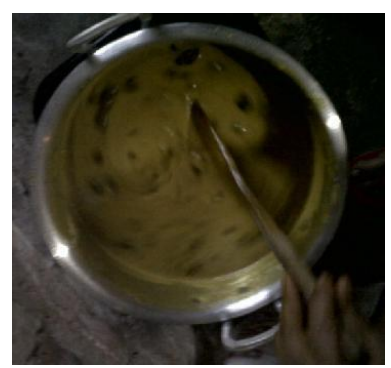

Gb.17: Proses perebusan

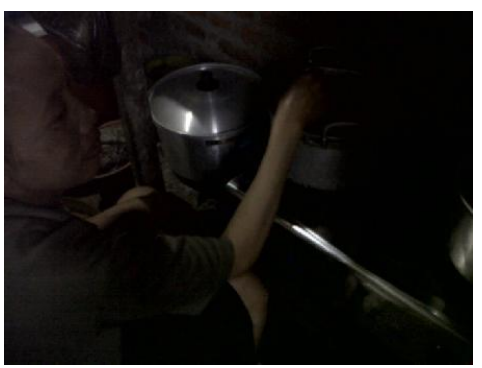

Gb. 18: Proses Pengadukan

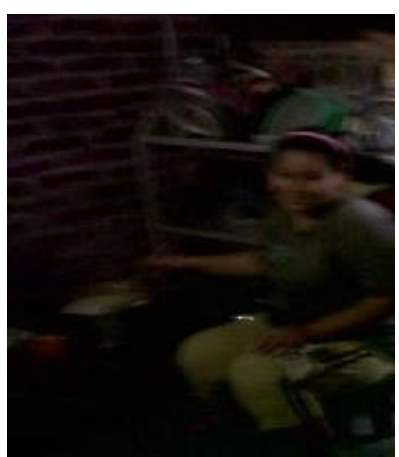

Gb.19: Proses pengadukan

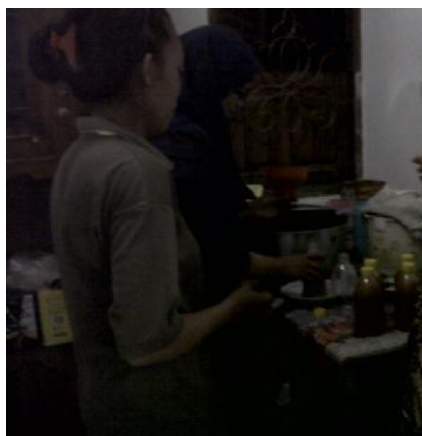

Gb. 20: Proses Pengemasan

Tahap Evaluasi: dilakukan dengan melakukan penilaian terhadap produk yang dihasilkan saat dilakukan pendampingan.

\section{HASIL DAN PEMBAHASAN}

\section{Toga Instan}

Setelah dilakukan pelatihan dan pendampingan pembuatan toga instan dan dilakukan pendampingan pengemasan serta penggunaan sealer, penjual jamu gendong telah dapat membuat produk toga instan yang telah dikemas dan di beri label. Adapun produk toga instan hasil pelatihan dan pendampingan tersebut meliputi 1. Kunyit asam instan. 2. Jahe instan, 3. Kunyit Putih instan 4. Temulawak instan. Produk tersebut seperti pada gambar berikut: 


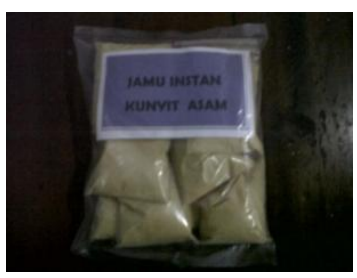

Gb.21 Kunyit asam instan

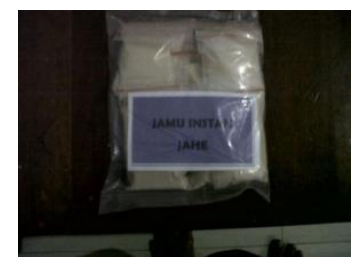

Gb: 22. Jahe Instan

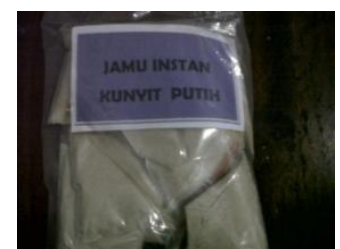

Gb23: Kunyit Putih

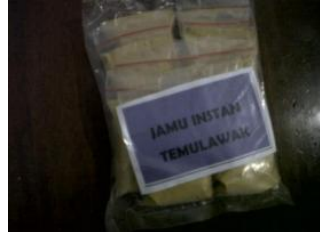

Gb. 24 Temulawak Instan

\section{Sirup Toga}

Kelompok penjual jamu gendong juga didampingi dalam pembuatan sirup toga. Adapun hasil pembuatan sirup toga dalam kemasan botol oleh pembuat jamu gendong adalah 1 . Sirup Temulawak. 2. Sirup Jahe. 3. Sirup Kunyit asam. 4. Sirup Kunyit putih. Produk tersebut seperti pada gambar berikut:

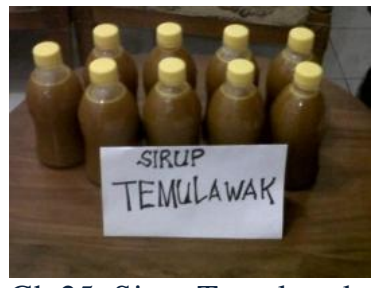

Gb.25: Sirup Temulawak

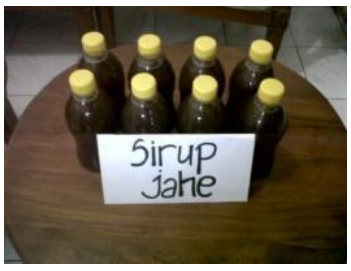

Gb 26: Sirup Jahe

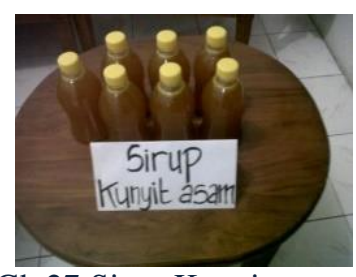

Gb 27:Sirup Kunyit asam

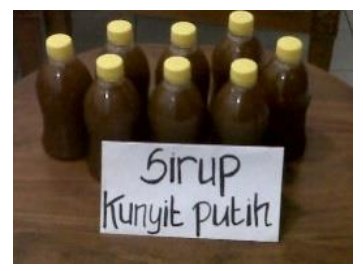

Gb28: Sirup Kunyit Putih

Bantuan fasilitas yang diberikan pada kelompok penjual jamu gendong seperti tersebut pada gambar berikut:

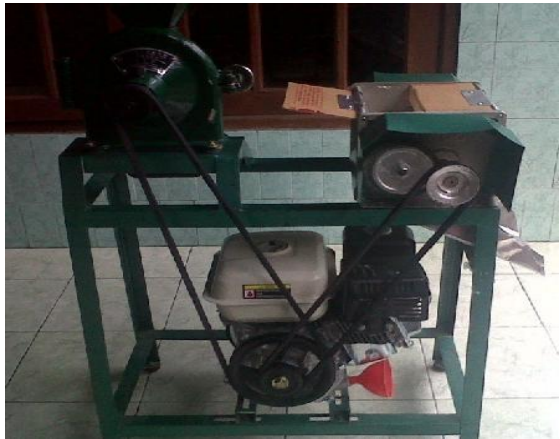

Gambar 29. Mesin Parut Toga

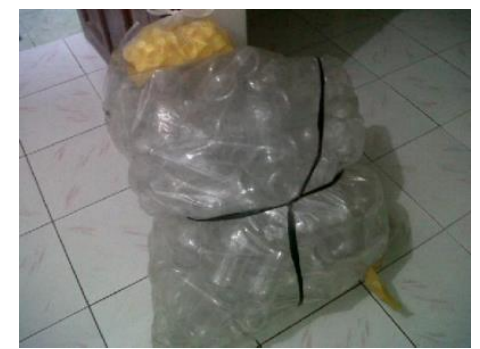

Gambar31: Botol Plastik

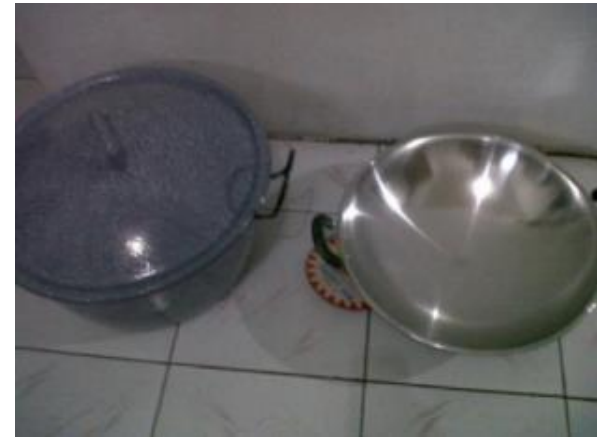

Gambar 30. Panci dan wajan

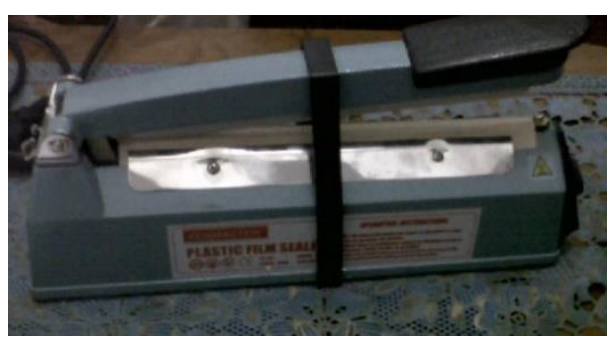

Gambar 32:. Sealer

Kelompok penjual jamu gendong antusias mengikuti pelatihan dan pendampigan pembuatan jamu instan dan (Toga instan) dan Sirup toga. Toga instan dan sirup toga mempunyai masa simpan yang lama dan dapat menjadi solusi saat musim hujan karena di musim hujan penjual 
jamu gendong tidak berjualan sehingga tidak berpenghasilan. Dengan membuat toga instan dan sirup toga maka penghasilan penjual jamu gendong meningkat dan rutin (Ajeg). Kegiatan pelatihan yang sama juga telah dilakukan oleh (Sulistyaningsih \& Mursiti, 2014) yang menyebutnya toga instan dengan istilah empon empon bergula juga mendapatkan hasil bahwa peserta pelatihan sangat antusias dalam mengikuti pelatihan pengolahan empon empon pasca panen. Pengelohan Toga instan ini perlu dikembangkan karena di Indonesia tumbuh berlimpah tanaman Toga sehingga empon empon tidak hanya digunakan sebagai bumbu masakan namun dapat dikembangkan sebagai produk unggulan daerah. Hal ini sesuai dengan hasil penelitian yang dilakukan oleh (Setyowati Jamu Gendong Instan 14356-288361-SM.Pdf, n.d.) bahwa Agroindustri unggulan di Karang anyar adalah jamu instan. Pemerintah juga memberikan perhatian pada jamu gendong dengan melakukan pelatihan, misalnya pada paguyuban Jamu Gendong Lestasi. Paguyuban ini telah berhasil melakukan diversifikasi olahan toga dan telah mendapatkan sertifikat Produksi industri Rumah Tangga (PIRT) dan sertifikasi Badan POM untuk Jamu bebas bahan kimia obat dan pengawet.(Christiyani, 2019)

Setelah dilakukan pelatihan dan pendampingan pembuatan jamu gendong yang hygienis maka pengetahuan dan ketrampilan penjual jamu gendong meningkat. Dimana tidak lagi menggunakan botol plastik yang selalu dipakai berulang ulang, dan telah menggunakan air yang telah direbus dalam pembuatan jamu gendong.

\section{KESIMPULAN}

1. Penjual jamu gendong telah telah melakukan diversifikasi usaha dengan membuat toga instan dan sirup toga.

2. Penjual jamu gendong meningkat pengetahuan dan ketrampilannya dalam pembuatan jamu gendong yang hygienis

3. Pendapatan penjuan jamu gendong meningkat dan ajeg (rutin)

\section{DAFTAR PUSTAKA}

Christiyani, A. (2019). Pembangunan Sosial oleh Paguyuban Jamu Gendong Lestari melalui Sektor Ekonomi Kreatif. Aspirasi: Jurnal Masalah-Masalah Sosial, 10(2). https://doi.org/10.46807/aspirasi.v10i2.1161

Hersoelistyorini, W., Aminah, S., Hardiyanti, D., Diana Hardiyanti, dan, Ilmu Keperawatan dan Kesehatan, F., Muhammadiyah Semarang, U., Budaya dan Bahasa Asing, F., \& 
Muhammadiyah Semarang Jl Kedung Mundu Raya, U. (2016). IbM PEDAGANG JAMU GENDONG DI DESA SUMBERSARI WONOLOPO. Jurnal DIANMAS, 5(1), $35-44$.

Nurrahman, Mifbakhuddin, D. P. (2010). Hubungan Sanitasi Dengan Total Mikroba Dan Total Kolifokm Pada Jamu Gendong Di Rt,1 Rw.2 Kelurahan Kedung Mundu Kecamatan Tembalang Kota Semarang. Jurnal Kesehatan Rajawali, II(4), 1-4.

Setyowati jamu gendong instan 14356-28836-1-SM.pdf. (n.d.).

Suci Asriani, P., Bonodikun, \& Yuliarti, E. (2015). Pemberdayaan Perempuan Pengrajin Jamu Gendong melalui Penerapan Teknologi Diversivikasi Produk Olahan. Jurnal Bisnis Tani, 1(1), 1-4.

Sulistyaningsih, T., \& Mursiti, S. (2014). PENGOLAHAN EMPON-EMPON PASCAPANEN DALAM UPAYA MENINGKATKAN DAYA JUAL PRODUK UNTUK MENUNJANG KESEJAHTERAAN KELUARGA. Jurnal Abdimas, 18(2).

Tivani, I. (2018). Uji Angka Lempeng Total (ALT) Pada Jamu Gendong Kunyit Asem di Beberapa Desa Kecamatan Talang Kabupaten Tegal. PSEJ (Pancasakti Science Education Journal), 3(1). https://doi.org/10.24905/psej.v3i1.901

Wulandari, R. A., \& Azrianingsih, R. (2014). Etnobotani jamu gendong berdasarkan persepsi produsen jamu gendong di Desa Karangrejo, Kecamatan Kromengan, Kabupaten Malang. Biotropika, 2(4). 